\title{
Editorial
}

\section{Space, the Final Frontier}

I am sometimes surprised by how much physical space still matters in today's academic library.

When asked what it is like to be a library director, the first thought that often enters my mind is how much time and effort I devote to library facilities - their design or re-design, collection storage options, public and staff work spaces, and, of course, the daily needs of building maintenance and custodial services.

One of my colleagues, who became the project manager for the decade-long and beautifully executed renovation of the central library at the Ohio State University, often brings up the tag line from Star Trek, "Space, the final frontier," as an ironic reference to our preoccupation in the work-a-day world with physical space management when we are supposed to be in the "digital or virtual age" of libraries.

When my work takes me, as it frequently does, to facility space planning and design issues, I try to draw on the research literature of our profession to help me make the most informed, and I hope "right," decisions. There are good books and articles from which to draw advice, best practices, and conceptual frameworks. Leighton and Weber's classic handbook Planning Academic and Research Library Buildings, now in its third edition and more than ten years old, is still good for nuts and bolts basics, such as allocation formulas for how much shelving you need for a certain number of print volumes. In 2003 Scott Bennett issued his provocative and influential study Libraries Designed for Learning. This was just in time to help me formulate the conceptual themes and vision for a major building redesign. I see it as a perfect example of how research and publication can influence on-the-ground library practice.

In the last issue of College $\mathcal{E}$ Research Libraries (January 2010), we brought you Gerke and Maness's article "The Physical and the Virtual: the Relationship between Library as Place and Electronic Collec-

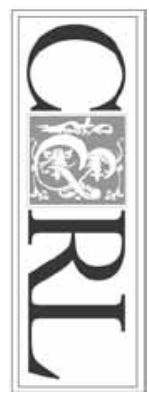
tions." I was heartened by the authors' conclusion that "investing in aesthetically pleasing facilities with ample study space and customized services could yield as much return in satisfied patrons as investing in electronic materials." Now in this current issue you are about to read, we have an interesting article by Jankowska and Marcum entitled "Sustainability Challenge for Academic Libraries: Planning for the Future of College and Research Libraries." The "greening" of our libraries is an important contemporary topic, and I am glad we are able to bring the research of Jankowska and Marcum to your attention.

Considering the amount of time academic librarians spend on space issues, we do not receive many manuscripts for consideration on this important topic. Please help us by sharing more of your good experience, research, and writing on this topic so that we can make the "right" decisions when it comes time to tackle changes in our library space. As you may know from your own hard experience, it can be a tough topic, full of politics and emotion. Try changing a library facility through re-design or re-organization, try new storage options for print collections, or try questioning existing service configurations and you are likely to encounter some resistance, to put it mildly. Be prepared with facts and figures and relevant research from the professional literature to argue and win your case for a better, forward looking library design.

Joseph Branin Editor, College $\mathcal{E}$ Research Libraries 